\title{
Increased Adipose Tissue Expression of Tumor Necrosis Factor- $\alpha$ in Human Obesity and Insulin Resistance
}

\author{
Gökhan S. Hotamisligil, * Peter Arner, ${ }^{\ddagger}$ José F. Caro, ${ }^{\mathbf{5}}$ Richard L. Atkinson, " and Bruce M. Spiegelman \\ *Dana Farber Cancer Institute and Department of Cell Biology Harvard Medical School, Boston, Massachusetts $02115 ;{ }^{\ddagger}$ Karolinska \\ Institute, Department of Medicine Huddinge University Hospital S-141 86 Huddinge, Sweden; ${ }^{8}$ Jefferson Medical College, Department of \\ Medicine, Philadelphia, Pennsylvania 19107; and "Medical College of Wisconsin, Department of Medicine Madison, Wisconsin 53706
}

\begin{abstract}
Obesity is frequently associated with insulin resistance and abnormal glucose homeostasis. Recent studies in animal models have indicated that TNF- $\alpha$ plays an important role in mediating the insulin resistance of obesity through its overexpression in fat tissue. However, the mechanisms linking obesity to insulin resistance and diabetes in humans remain largely unknown. In this study we examined the expression pattern of TNF- $\alpha$ mRNA in adipose tissues from 18 control and 19 obese premenopausal women by Northern blot analysis. TNF- $\alpha$ protein concentrations in plasma and in conditioned medium of explanted adipose tissue were measured by ELISA. Furthermore, the effects of weight reduction by dietary treatment of obesity on the adipose expression of TNF- $\alpha$ mRNA were also analyzed in nine premenopausal obese women, before and after a controlled weight-reduction program.

These studies demonstrated that obese individuals express 2.5 -fold more TNF- $\alpha$ mRNA in fat tissue relative to the lean controls $(P<\mathbf{0 . 0 0 1})$. Similar increases were also observed in adipose production of TNF- $\alpha$ protein but circulating TNF- $\alpha$ levels were extremely low or undetectable. A strong positive correlation was observed between TNF- $\alpha$ mRNA expression levels in fat tissue and the level of hyperinsulinemia $(P<0.001)$, an indirect measure of insulin resistance. Finally, body weight reduction in obese subjects which resulted in improved insulin sensitivity was also associated with a decrease in TNF- $\alpha$ mRNA expression (45\%, $P<0.001$ ) in fat tissue. These results suggest a role for the abnormal regulation of this cytokine in the pathogenesis of obesity-related insulin resistance. (J. Clin. Invest. 1995. 95:2409-2415.) Key words: cytokines - fat • non-insulindependent diabetes mellitus • weight loss $\bullet$ insulin action
\end{abstract}

Address correspondence to Bruce M. Spiegelman, Dana Farber Cancer Institute, 44 Binney Street, Boston, MA 02115. Phone: 617-632-4657; FAX: 617-632-4655. E-mail: Bruce Spiegelman@dfci.harvard.edu.

Received for publication 28 November 1994 and in revised form 18 January 1995.

J. Clin. Invest.

(C) The American Society for Clinical Investigation, Inc.

0021-9738/95/05/2409/07 \$2.00

Volume 95, May 1995, 2409-2415

\section{Introduction}

Obesity is the most common metabolic disease in the industrial world and affects $>30 \%$ of the adult population in the U.S. (1). Furthermore, obesity is a major risk factor for non-insulindependent diabetes mellitus (NIDDM) ${ }^{1}$ and $>80 \%$ of NIDDM patients in the USA are obese (1). Since insulin resistance is a ubiquitous correlate of obesity and an important component of NIDDM, insulin resistance is generally considered a major pathophysiological link between these two disorders $(2,3)$. In addition, insulin resistance is also believed to play a role in other pathological states associated with obesity including dyslipidemias, atherosclerosis, hypertension, and cardiovascular disorders $(3,4)$. Although the importance of the link between obesity and insulin resistance has long been recognized, (4) the molecular basis of this connection has remained elusive.

TNF- $\alpha$ is a pluripotent cytokine primarily, but not exclusively, produced from macrophages (5-7). In addition to its role in host defense, TNF- $\alpha$ also has important effects on whole body lipid and glucose metabolism $(7,8)$. We have previously demonstrated that fat tissue is a significant source of endogenous TNF- $\alpha$ production and the expression of this cytokine in adipose tissue is elevated in most of the models of rodent obesity examined to date (9-11). This abnormal expression of TNF$\alpha$ in adipose tissue plays a critical role as a mediator of peripheral insulin resistance in rodent obesity, and neutralization of TNF- $\alpha$ in obese and insulin-resistant animals results in significant increases in peripheral insulin sensitivity (9).

Recent studies have indicated that defective signaling from the insulin receptor is an important component of insulin resistance associated with obesity in both animal models and humans (12-16). Studies on TNF- $\alpha$-mediated insulin resistance in cultured cells as well as in whole organisms have also demonstrated that TNF- $\alpha$ induces insulin resistance, at least in part, through its ability to inhibit intracellular signaling from the insulin receptor $(17,18)$. Moreover, this inhibition can be reversed by neutralizing TNF- $\alpha$ in vivo (19).

The expression of TNF- $\alpha$ in the adipose tissue of obese humans has not been examined to date. Here we demonstrate that the expression of TNF- $\alpha$ in adipose tissue is significantly elevated in human obesity and this elevation is strongly correlated with the level of hyperinsulinemia, which in the presence of normoglycemia, is a marker of insulin resistance (2).

1. Abbreviations used in this paper: BMI, body mass index; NIDDM, non-insulin-dependent diabetes mellitus. 


\section{Methods}

Patients and controls. We studied 37 premenopausal females, (18 lean and 19 obese, recruited in University of Eastern Virginia Medical School and Huddinge Hospital, Department of Medicine, Huddinge, Sweden) between the ages of 25 and 45 . The characteristics of the subjects are summarized in Table I. Inclusion criteria for subjects included: $(a)$ Body mass index (BMI = weight in kilograms divided by the square of height in meters) $>30 \mathrm{~kg} / \mathrm{m}^{2}$ for obese and $<25 \mathrm{~kg} / \mathrm{m}^{2}$ for lean; (b) mixed Caucasian ethnic background; $(c)$ absence of any systemic disease; $(d)$ absence of any infections; $(e)$ absence of current medication affecting glucose homeostasis or sympathetic nervous system; and $(f)$ absence of weight change of $>10 \%$ in the last 3 mo. All subjects had a medical history and a physical examination before participating in the study. For baseline studies, venous blood samples were collected after a 10-h fast, plasma was separated immediately, and aliquots were kept refrigerated at $4^{\circ} \mathrm{C}$ or frozen at $-80^{\circ} \mathrm{C}$. Subcutaneous fat tissues were obtained from the abdominal region by a fat biopsy performed under local anesthesia, and immediately frozen in liquid nitrogen for future mRNA analysis. In additional studies, abdominal subcutaneous adipose tissues were obtained intraoperatively from six lean $(B M I=24.9 \pm 1.2$ $\left.\mathrm{kg} / \mathrm{m}^{2}\right)$ and nine obese $\left(\mathrm{BMI}=39.3 \pm 2.2 \mathrm{~kg} / \mathrm{m}^{2}\right.$ ) female patients undergoing elective surgery (Huddinge Hospital, Sweden). The lean subjects were operated on because of gallstones. None had jaundice and all were drug free. The obese subjects underwent gastric binding because of their obesity and were otherwise healthy and drug free. The subjects were fasted overnight and only saline was given intravenously before the fat biopsy. Anesthesia was induced with a short-acting barbiturate and maintained with a mixture of oxygen, nitrous oxide, and fentanyl. After the biopsy, the fat tissues were immediately processed and used for TNF- $\alpha$ protein measurements.

In parallel, nine obese female subjects (recruited at the Karolinska Institute, Department of Medicine, Huddinge, Sweden) were studied before and after a weight reduction program targeting a 17\% decrease in BMI. The subjects were otherwise healthy and drug free. They had not undertaken a slimming diet for at least $1 \mathrm{y}$ before the study. All subjects were sedentary. They were given a liquid protein diet (500 $\mathrm{kCal} / \mathrm{d}$ ) supplemented with vitamins, essential fatty acids, and minerals (Nutrilette®, Nycomed Pharma, Oslo, Norway) for 12 wk. They then returned to an isocaloric standard diet. The subjects were investigated at two occasions: first, immediately before the weight reduction program and second, 4-6 wk after they had finished the 12-wk weight reduction program. At the latter time, body weight was stable for at least $3 \mathrm{wk}$. Venous blood samples and abdominal subcutaneous fat tissues (by fat biopsy under local anesthesia) were obtained after an overnight fast. The left and right sides were used in a randomized order. The characteristics of the subjects in this group are summarized in Table II. All of the above studies were approved by the institutional review boards and informed consent was obtained from each subject.

Northern blot analysis. Total RNA was extracted from fat tissue samples by a Cs-chloride extraction protocol (20). Total RNA ( $20 \mu \mathrm{g})$ was denatured in formamide and formaldehyde at $55^{\circ} \mathrm{C}$ for $15 \mathrm{~min}$ and separated by electrophoresis in formaldehyde-containing agarose gels, as described (9). RNA was blotted onto biotrans membranes, ultraviolet cross-linked (Stratagene, Inc., La Jolla, CA), and baked for $0.5 \mathrm{~h}$. Hybridization and washes were done as directed by the manufacturer. Cloning of the complementary DNA for aP2 (also known as adipocyte fatty acid-binding protein, A-FABP) has been published (21). Complementary DNA probes for human TNF- $\alpha$ and tumor TNF- $\beta$ are cloned in our laboratory based on the published sequences $(6,22)$. IL-1 $\beta$ and IL-6 cDNA probes were gifts from Dr. Bruce Dezube (Dana Farber Cancer Institute, Boston, MA). DNA probes were radioactively labeled to specific activities of at least $10^{9}$ disintegrations per minute $/ \mu \mathrm{g}$ with $\left[{ }^{32} \mathrm{P}\right] \alpha$-dCTP $(6,000 \mathrm{Ci} / \mathrm{mmol})$ by the random priming method, as described (9). Quantitation of Northern blots were performed using a PhosphorImager (Molecular Dynamics, Inc., Sunnyvale, CA). Differences in loading were adjusted to $\beta$-actin expression and the amount of
Table I. Characteristics of the Study Group

\begin{tabular}{|c|c|c|c|c|c|}
\hline & \multicolumn{2}{|c|}{ Lean $(n=18)$} & \multicolumn{2}{|c|}{ Obese $(n=19)$} & \multirow{2}{*}{$\begin{array}{c}P \text { value } \\
\text { (Student's } \\
t \text { test) }\end{array}$} \\
\hline & Mean \pm SE & Range & Mean \pm SE & Range & \\
\hline Age (yrs) & $34.4 \pm 1.2$ & $26-45$ & $34.4 \pm 1.5$ & $25-45$ & NS \\
\hline BMI* & & & & & \\
\hline$\left(\mathrm{kg} / \mathrm{m}^{2}\right)$ & $21.38 \pm 0.3$ & $19.6-24.1$ & $39.9 \pm 1.4$ & $31.6-53.8$ & 0.0001 \\
\hline Waist/hip ${ }^{\ddagger}$ & & & & & \\
\hline $\begin{array}{l}(\mathrm{m} / \mathrm{m}) \\
\text { Insulin }\end{array}$ & $0.85 \pm 0.02$ & $0.77-0.98$ & $0.90 \pm 0.01$ & $0.73-0.69$ & 0.04 \\
\hline$(\mu \mathrm{U} / \mathrm{ml})$ & $13.06 \pm 1.2$ & $5.9-25.8$ & $46.4 \pm 3.9$ & $13.3-83.1$ & 0.0001 \\
\hline $\begin{array}{l}\text { Glucose } \\
\text { (mg/dl) }\end{array}$ & $83.1 \pm 1.3$ & $72.9-91.8$ & $95.9 \pm 3.1$ & $73.8-131.5$ & 0.006 \\
\hline $\begin{array}{l}\text { Triglyceride } \\
\text { (mg/dl) }\end{array}$ & $83.1 \pm 7.3$ & $24.0-140.0$ & $136.2 \pm 14.8$ & $58.0-248.0$ & 0.002 \\
\hline $\begin{array}{c}\text { Cholesterol } \\
(\mathrm{mg} / \mathrm{dl})\end{array}$ & $158.1 \pm 8.6$ & $88.0-210.0$ & $181.8 \pm 6.9$ & $142.0-234.0$ & 0.04 \\
\hline
\end{tabular}

To convert values for insulin to pmol/L liter multiply by 7.175 ; to convert values for glucose to $\mathrm{mmol} /$ liter multiply by 0.05551 ; to convert values for triglycerides to mmol/liter multiply by 0.01129 ; and to convert values for cholesterol to $\mathrm{mmol} /$ liter multiply by 0.02586 . * BMI was calculated as the weight in kilograms divided by the square of the height in meters. ${ }^{\ddagger}$ The ratio of the waist to the hip circumferences.

TNF- $\alpha$ or aP2 mRNA was expressed as percentage of an arbitrary control set to $100 \%$.

Protein measurements. For measurements of TNF- $\alpha$ protein secretion by adipose tissue, freshly obtained fat specimens were cut into pieces (25-50 mg) under sterile conditions, weighed, rinsed once in sterile Krebs-Ringer phosphate buffer ( $\mathrm{pH} \mathrm{7.4)}$ and incubated (1.0 ml media/100 mg tissue) in a medium consisting of Krebs-Ringer phosphate ( $\mathrm{pH} 7.4$ ), endotoxin-free BSA $(4 \mathrm{~g} / 100 \mathrm{ml}$ ), and glucose ( $1 \mathrm{mg} /$ $\mathrm{ml})$ at $37^{\circ} \mathrm{C}$ in a shaking incubator with air as the gas phase (9). Incubation media were collected at 1 and $2 \mathrm{~h}$ and frozen in liquid nitrogen. At the end of the experiment total DNA was extracted from fat tissues used in each experiment, as described (9), and secreted protein values were calculated as both picograms per milligrams of DNA and picograms per milligram of adipose tissue. Total secreted proteins and the pattern of secretion was determined by SDS-PAGE. Protein concentrations of TNF- $\alpha$ was measured by ELISA (Biosource International, Camarillo, CA), in supernatants of explanted tissues as well as in plasma obtained from subjects.

Statistical analysis. Data are expressed as means \pm SE. Individual variables were compared by using two-tailed Student's $t$-test analysis. The relationship between individual variables were determined by linear correlation analysis. StatView $512^{+}$(Abacus Concepts, Inc., Berkeley, CA) statistical software was used in all analyses. All $P$ values reported are two-sided.

\section{Results}

Study group. Table I summarizes the characteristics of the 37 premenopausal female subjects ( 18 lean and 19 obese) at the time of entry. All subjects were of mixed-Caucasian ethnic origin and lean and obese subjects were similar in age $(34.4 \pm 1.2$ and $34.4 \pm 1.5$, respectively). The subjects were not markedly hyperlipidemic based on fasting plasma measurements. Although the obese group had higher average fasting plasma glucose levels compared to controls, all values were within normoglycemic range except one which was borderline $(131.5 \mathrm{mg}$ / dl or $7.5 \mathrm{mmol} /$ liter). However, the obese subjects were significantly hyperinsulinemic (presumably compensatory), indicating the presence of insulin resistance. 

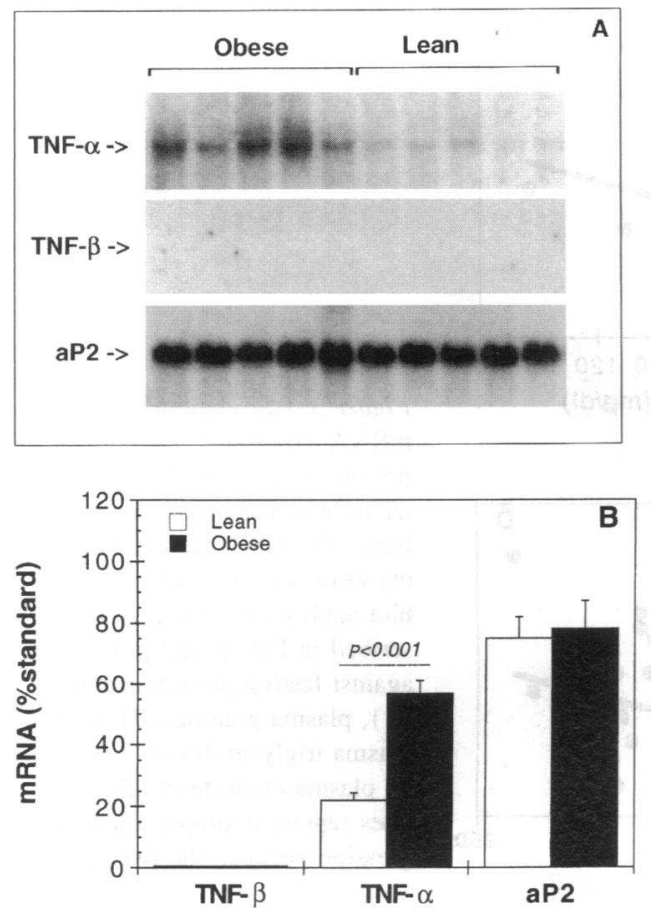

Figure 1. Expression of TNF- $\alpha$ mRNA in adipose tissue from lean and obese female human subjects. $(A)$ A representative Northern blot showing the elevated TNF- $\alpha$ mRNA expression in adipose tissues of fivelean and five-obese subjects. TNF- $\beta$ and aP2 mRNA expression in the same Northern blot are shown for comparison. $(B)$ Quantitation of TNF$\alpha$ mRNA expression in 18 lean and 19 obese subjects. $\beta$-actin expression was used as a standard to correct the loading differences and mRNA is expressed as percentage of standard. Similar quantitation of aP2 is shown for comparison.

Expression of TNF- $\alpha$ mRNA in adipose tissue. To examine the expression of the TNF- $\alpha$ gene we extracted total RNA from subcutaneous adipose tissues of lean and obese human subjects. Northern blot analysis demonstrated that TNF- $\alpha$ mRNA is endogenously present in human adipose tissue (Fig. $1 A$ ). The level of TNF- $\alpha$ mRNA expression was strikingly elevated in adipose tissues obtained from obese individuals compared to age-matched lean controls (Fig. $1 A$ and $B$ ). When normalized to the $\beta$-actin mRNA present in each adipose tissue sample, a 2.5 -fold increase was observed in the amount of TNF- $\alpha$ mRNA in the obese group $(21.9 \pm 10.4$ vs $56.9 \pm 18.6 \%, P<0.001)$. To test the specificity of this pattern of TNF- $\alpha$ mRNA expression, we examined several other cytokines and fat specific genes. TNF- $\beta$ (lymphotoxin alpha, Fig. 1), IL-1 $\beta$, and IL-6 mRNA was not detected in any of the subjects (data not shown). Moreover, the expression of a fat-specific gene, aP2, was not different between lean and obese subjects (Fig. 1). These results suggested that elevated mRNA expression was specific for TNF- $\alpha$ and was not the result of a generalized aberrant expression of the cytokine family or fat-specific genes. These controls also demonstrate that there was no systemic bias in quantitation when comparing mRNA from fat tissue of lean versus obese subjects.

$T N F-\alpha$ protein production. A critical question is whether the differences in mRNA levels were reflected in the amounts of local and systemic (circulating) TNF- $\alpha$ protein. We exam-

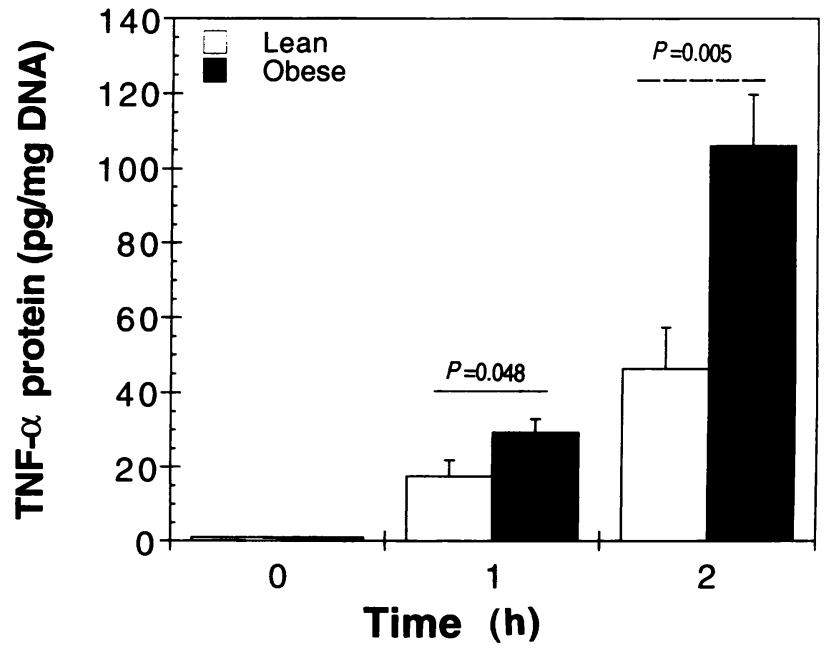

Figure 2. Secretion of TNF- $\alpha$ protein from the explanted adipose tissue of lean and obese female subjects. After 1 and $2 \mathrm{~h}$ incubation of fresh adipose tissue, TNF- $\alpha$ protein was measured in conditioned media by ELISA. Protein quantities were expressed as picograms protein per milligram total tissue DNA that is extracted from the adipose tissue at the end of the incubation period.

ined local protein production from explanted adipose tissue and observed TNF- $\alpha$ secretion (Fig. 2). When expressed as the mass of TNF- $\alpha$ protein secreted per unit of tissue DNA, the adipose tissue obtained from obese subjects secreted higher quantities of TNF- $\alpha$ protein compared to the lean controls (at $1 \mathrm{~h}$, lean, $17.1 \pm 4.2$ vs obese, $28.9 \pm 3.4$; and at $2 \mathrm{~h}$, lean, $46.3 \pm 11.0$ vs obese, $100.3 \pm 9.6 \mathrm{pg} / \mathrm{mg}$ DNA, $P=0.048$ and $P=0.005$, respectively). Similarly, when TNF- $\alpha$ protein secretion was expressed as a function of adipose tissue mass, obese individuals were found to secrete higher amounts of TNF- $\alpha$ protein compared to the lean controls (at $1 \mathrm{~h}$, lean, $21.2 \pm 3.9$ vs obese, $32.3 \pm 2.5$; and at $2 \mathrm{~h}$, lean, $40.7 \pm 6.1$ vs obese, $81.7 \pm 13.5 \mathrm{pg} / \mathrm{mg}$ fat tissue, $P=0.03$ and $P=0.01$, respectively). To ensure that this measure was not biased due to a general loss of viability upon explantation of the adipose tissues, total secreted proteins were analyzed by SDS-PAGE. There were no significant differences in the general pattern of protein production and no protein degradation was observed in any of the samples in both groups. In addition, in two subjects we incubated isolated adipocytes and obtained very similar pattern and quantity of TNF- $\alpha$ secretion as compared to tissue explants from the same individuals (data not shown). Therefore, we concluded that the secretion of TNF- $\alpha$ by the obese tissue is greater than the lean and appears to be produced by the adipocytes. We also measured circulating TNF- $\alpha$ protein concentrations in all subjects. TNF- $\alpha$ protein was detectable in the plasma of only $2 / 18$ lean $(11.1 \%)$ and $2 / 19$ obese $(10.5 \%)$ subjects at very low levels ( 1.6 and $2.2 \mathrm{pg} / \mathrm{ml}$ in lean and 1.2 and 5.1 in obese subjects).

$T N F-\alpha$ expression and metabolic parameters. We next analyzed the relationship between the levels of TNF- $\alpha$ mRNA in fat tissue and various metabolic parameters measured in lean and obese subjects. A very strong positive correlation was observed between TNF- $\alpha$ expression and fasting plasma insulin levels (Fig. $3 A ; r=0.82, P<0.001$ ). A positive correlation was also present between TNF- $\alpha$ expression and BMI $(r=0.70$, 

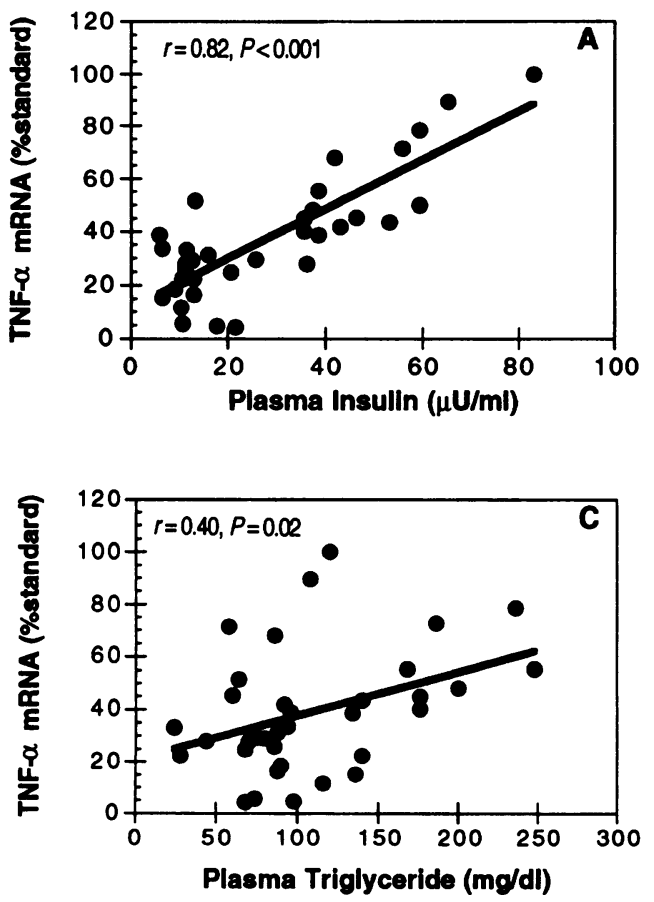
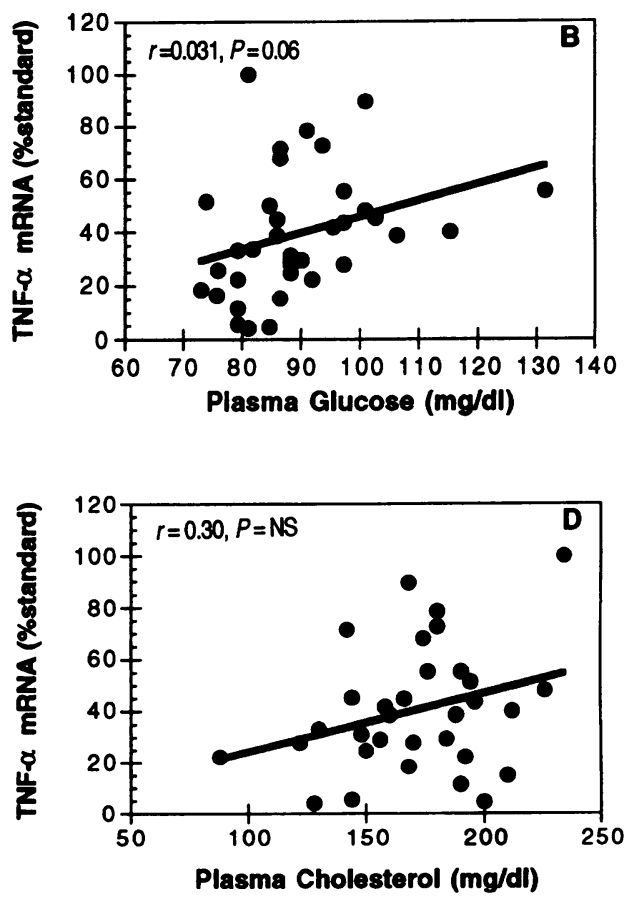

Figure 3. Correlations of TNF- $\alpha$ mRNA expression levels in adipose tissue and metabolic parameter in lean and obese female subjects. The TNF- $\alpha$ expression levels were determined by Northern blot analysis, quantitated as described in Fig. 1, and plotted against fasting plasma insulin $(A)$, plasma glucose $(B)$, total plasma triglycerides $(C)$, and total plasma cholesterol $(D)$. The lines represent simple linear regression between the two variables.
$P<0.001)$. It should be noted that there is a trend toward bimodality in BMI values as a result of the selection criteria used to differ lean and obese subjects. As expected, there was also a positive correlation between BMI and fasting insulin levels $(r=0.77, P<0.001)$. A relatively weaker positive correlation was observed between TNF- $\alpha$ expression and fasting plasma triglyceride levels (Fig. $3 C ; r=0.40, P=0.02$ ). In contrast, no statistically significant correlations was present between TNF- $\alpha$ expression in adipose tissue and age, waist to hip ratios, plasma glucose, and total cholesterol levels. It is worth noting that these latter parameters were only marginally different between the lean and obese group.

Effects of weight reduction on TNF- $\alpha$ expression. Weight reduction is among the most effective treatment for abnormalities in glucose homeostasis seen in obesity (23). It often improves systemic insulin resistance and can reduce the compensatory hyperinsulinemia. We asked whether a relationship exists between weight loss and subsequent improvements in glucose homeostasis and TNF- $\alpha$ expression in fat tissue. For this we obtained fat biopsies and blood samples from nine obese subjects before and after a $17 \%$ weight reduction. The characteristics of these subjects are summarized in Table II. After the weight reduction, there was a significant decrease in serum insulin levels (from $43.1 \pm 5.1$ to $26.2 \pm 3.5, P=0.001$ ) in all obese subjects without any change in plasma glucose, indicating an improvement in insulin sensitivity. As shown in Fig. 4, $A$ and $B$, a parallel decrease was also evident in TNF- $\alpha$ expression in adipose tissue from $7 / 9$ (from $49.4 \pm 5.1$ to $26.6 \pm 3.6 \%, P$ $<0.001$ ). No change in TNF- $\alpha$ expression was evident in one subject (Patient 1) and a slight elevation was observed in the other (Patient 2) at the end of the protocol. These alterations were again specific to TNF- $\alpha$ and no changes were observed in the expression of aP2 in adipose tissue. TNF- $\beta$ (Fig. $4 A$ ), IL-1 $\beta$, and IL-6 (data not shown) were not detectable at both states.

\section{Discussion}

We have previously shown that TNF- $\alpha$ is a key mediator of insulin resistance in many different rodent models of obesity, through its obesity-related overexpression in adipose tissue ( 9 , 11). Neutralization of TNF- $\alpha$ in obese and insulin-resistant rats resulted in significant increases in peripheral insulin sensitivity, as measured by hyperinsulinemic-euglycemic clamp studies (9). In addition, both dietary and pharmacological treatment of

Table II. Characteristics of the Obese Women before and after Weight Reduction

\begin{tabular}{|c|c|c|c|c|c|}
\hline & \multicolumn{2}{|c|}{ Before $(n=9)$} & \multicolumn{2}{|c|}{ After $(n=9)$} & \multirow{2}{*}{$\begin{array}{c}P \text { value } \\
\text { (Student's } \\
t \text { test) }\end{array}$} \\
\hline & Mean $\pm S E$ & Range & Mean $\pm S E$ & Range & \\
\hline Age (yr) & $36.5 \pm 2.9$ & $25-45$ & $36.5 \pm 2.9$ & $25-45$ & NS \\
\hline $\begin{array}{l}\text { BMI* } \\
\quad\left(\mathrm{kg} / \mathrm{m}^{2}\right)\end{array}$ & $37.6 \pm 1.1$ & $31.6-41.5$ & $32.1 \pm 1.2$ & $27.3-37.1$ & 0.003 \\
\hline $\begin{array}{c}\text { Waist/hip } \\
(\mathrm{m} / \mathrm{m})\end{array}$ & $0.93 \pm 0.02$ & $0.87-0.98$ & $0.90 \pm 0.02$ & $0.82-1.0$ & NS \\
\hline $\begin{array}{l}\text { Insulin } \\
\qquad(\mu \mathrm{U} / \mathrm{ml})\end{array}$ & $43.1 \pm 5.1$ & $13.3-59.3$ & $26.2 \pm 3.5$ & $13.6-41.8$ & 0.001 \\
\hline $\begin{array}{l}\text { Glucose } \\
\text { (mg/dl) }\end{array}$ & $92.3 \pm 3.5$ & $73.8-102.7$ & $90.6 \pm 3.0$ & $84.6-93.6$ & NS \\
\hline $\begin{array}{l}\text { Triglyceride } \\
(\mathrm{mg} / \mathrm{dl})\end{array}$ & $97.7 \pm 20.2$ & $58.0-200.0$ & $90.0 \pm 17.1$ & $38.0-150.0$ & NS \\
\hline $\begin{array}{c}\text { Cholesterol } \\
(\mathrm{mg} / \mathrm{dl})\end{array}$ & $175.7 \pm 11.7$ & $142.0-226.0$ & $158.0 \pm 10.3$ & $116.0-204.0$ & NS \\
\hline
\end{tabular}

To convert values for insulin to pmol/liter multiply by 7.175 ; to convert values for glucose to $\mathrm{mmol} / \mathrm{liter}$ multiply by 0.05551 ; to convert values for triglycerides to mmol/liter multiply by 0.01129 ; and to convert values for cholesterol to $\mathrm{mmol} /$ liter multiply by 0.02586 . * BMI was calculated as the weight in kilograms divided by the square of the height in meters. ${ }^{\ddagger}$ The ratio of the waist to the hip circumferences. 

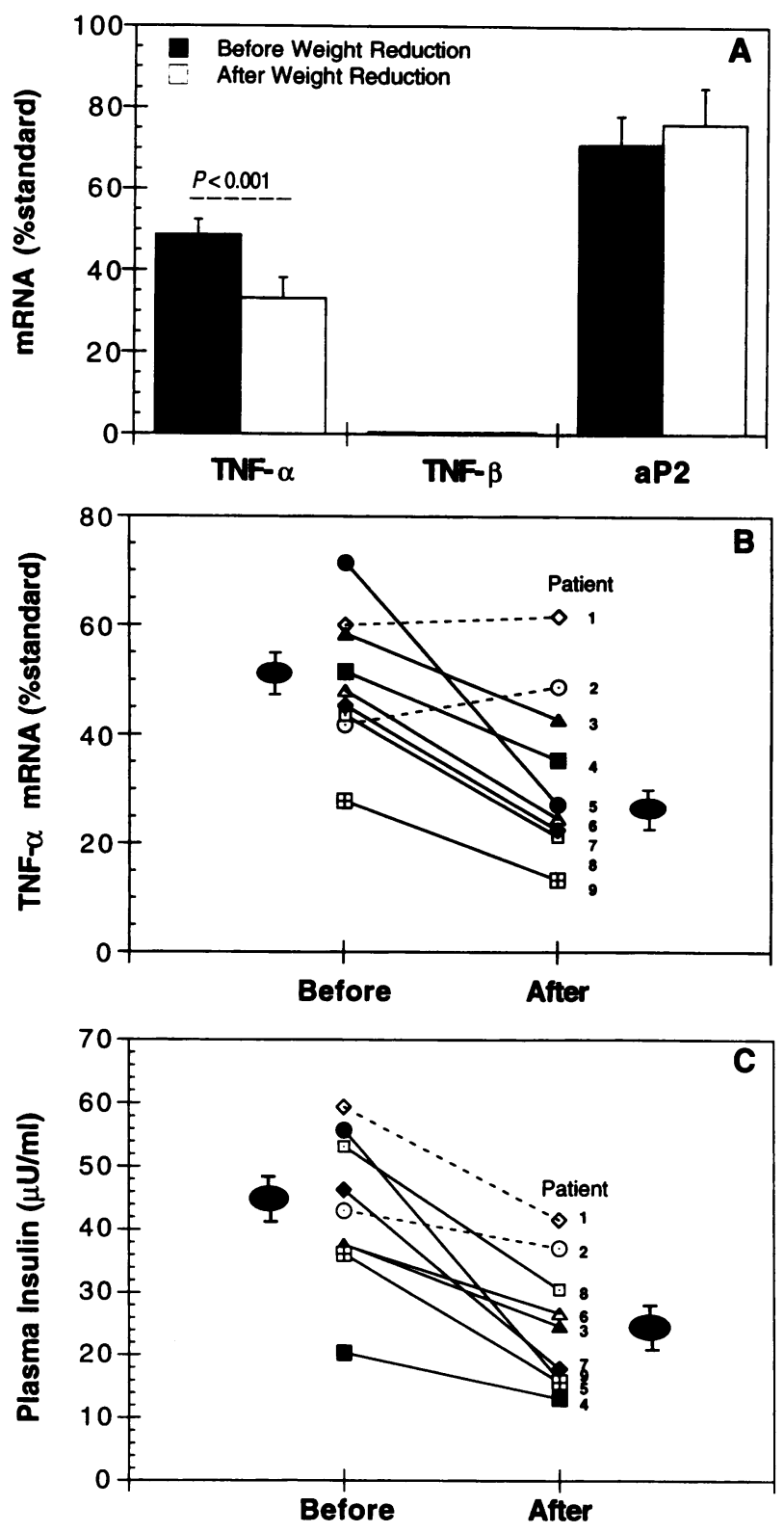

Figure 4. TNF- $\alpha$ mRNA expression and fasting plasma insulin levels in adipose tissue before and after a weight reduction program in obese female subjects. The TNF- $\alpha$ mRNA expression levels were determined by Northern blot analysis, quantitated as described in Fig. 1, $(A)$ Cumulative results; $(B)$ individual changes in TNF- $\alpha$ mRNA expression; and $(C)$ individual changes in plasma insulin before and after weight loss. For each subject the values at the beginning and at the end of the study are connected by lines. The solid lines represent the subjects where there was a decrease in TNF- $\alpha$ expression. The dotted lines represent the subjects where there was no change or increase in TNF- $\alpha$ expression. Circles and bars indicate means $\pm \mathrm{SE}$.

obese and diabetic animals led to a significant decrease in the amount of TNF- $\alpha$ expression in adipose tissue (11).

Overexpression of TNF- $\alpha$ in adipose tissue is a common, if not a universal correlate of obesity and insulin resistance in animal models $(9,10)$. Thus, it was critical to examine the expression of this cytokine in adipose tissues of obese humans relative to lean subjects. In this study we have demonstrated that adipose tissues of obese subjects also express elevated levels of TNF- $\alpha$ mRNA and secrete increased amounts of the corresponding protein (Figs. 1 and 2). Strong positive correlations were observed between the expression levels of TNF- $\alpha$ mRNA in fat tissue and the extent of hyperinsulinemia (Fig. 3). Since levels of circulating insulin is an indicator of insulin resistance in obese, euglycemic patients, these results are suggestive of a role for TNF- $\alpha$ in the insulin resistance of obesity. Direct measurements of in vivo insulin sensitivity by glucose clamps in studies using TNF- $\alpha$-neutralizing reagents will be necessary to definitively address the relationship between TNF- $\alpha$ expression and insulin action in humans. However, these correlations are striking considering the heterogeneous etiology of obesity in human populations.

In contrast to the variables discussed above, we observed no correlation between waist/hip ratios, fasting plasma glucose, plasma cholesterol levels, and TNF- $\alpha$ mRNA expression in fat tissue. The lack of correlation with waist/hip ratios suggests that TNF- $\alpha$ expression is not tightly linked to differences in regional fat deposition in our study group. However, previous studies have indicated the importance of regional fat deposition as a determinant of increased risk for insulin resistance and NIDDM in obese patients (24). Further clinical studies in larger groups will be necessary to address this issue. The absence of correlation between the plasma glucose levels and TNF- $\alpha$ expression is not surprising since the group reported here did not contain patients with fasting hyperglycemia.

Amelioration of obesity through diet and exercise is the first line of therapy for the obese diabetic patient (23). In addition to the positive correlations mentioned above, we demonstrate here that corrective decreases in body weight and hyperinsulinemia through a weight loss program also results in reductions in TNF- $\alpha$ expression in adipose tissue. Despite the small number of the subjects in this study we were able to obtain statistical significance in these changes in TNF- $\alpha$ expression after weight loss. In two patients (Patient 1 and 2 , Fig. $4 b$ ) there was no reduction in adipose TNF- $\alpha$ expression after weight loss. Interestingly, these two subjects responded poorly to weight reduction in terms of decreases in plasma insulin levels and were still hyperinsulinemic at the end of the protocol (with plasma insulin levels of 32.6 and $41.8 \mu \mathrm{U} / \mathrm{ml}$, respectively). Although these subjects may be atypical, it is possible that regulation of TNF- $\alpha$ expression through weight reduction is not similar in all obese subjects and reflect the heterogeneity in the relationship between insulin levels and TNF- $\alpha$ mRNA expression. Nevertheless, these results suggested that TNF- $\alpha$ expression is effectively regulated during metabolic perturbations and tightly linked to the abnormalities in metabolic status such as elevated insulin levels in the majority of the cases studied here.

We did not observe elevations in circulating TNF- $\alpha$ levels in this study. In a recent study in pediatric age group, Boeck et al. also reported lack of detectable TNF- $\alpha$ in serum of obese patients (25). However, here we demonstrated an elevation in the amount of TNF- $\alpha$ protein produced per mass or per unit DNA from the fat tissues of obese individuals compared to lean control subjects. This was also the case in the rodent models studied to date suggesting that TNF- $\alpha$ action in the insulin resistance of obesity is likely to be through an autocrine-paracrine mechanism rather than through an endocrine route ( 9 , 10 ). In obese and insulin-resistant $\mathrm{fa} / \mathrm{fa}$ rats neutralization of 
TNF- $\alpha$ results in increased insulin sensitivity in muscle tissue, although expression is not readily detectable at this site (19). It is therefore possible that expression of TNF- $\alpha$ in adipose tissue causes the generation of secondary mediators that effect insulin response at distant sites.

If fat-derived TNF- $\alpha$ is playing an important role in inducing insulin resistance in obesity, what could be the mechanism of action? In the fa/fa rat model of obesity with severe insulin resistance but very mild diabetes, TNF- $\alpha$-induced peripheral insulin resistance involves, at least in part, the inhibition of insulin-stimulated autophosphorylation of the insulin receptor and phosphorylation of insulin receptor substrate 1 in vivo (19). However, it has been demonstrated in humans that reductions in the kinase activity of insulin receptor is observed mainly in patients with NIDDM, but not in obese, nondiabetic subjects $(15,16)$. Therefore, a role for TNF- $\alpha$ in obesity-linked insulin resistance in humans may involve additional steps in the insulin action pathways including regulation of glucose transporter number or activity, or modulation of steps downstream of insulin receptor and insulin receptor substrate 1 in the signal transduction cascade.

Another potential discordance between the role of TNF- $\alpha$ in obesity-linked insulin resistance in animal models and humans is the relative contribution of hepatic insulin resistance. Previous studies in the fa/fa rat, demonstrated that TNF- $\alpha$ neutralization primarily effects peripheral glucose disposal with little or no effect on hepatic glucose output (9). While the inability to suppress hepatic glucose output is an important component of fasting hyperglycemia and NIDDM, studies in obese insulin-resistant humans (without NIDDM) have demonstrated that the severity of the hepatic insulin resistance is much smaller than the defects in insulin-stimulated glucose disposal (26). Furthermore, the hepatic insulin resistance in obese, nondiabetic subjects was found to be in the form of decreased insulin sensitivity, while the peripheral insulin resistance involved both decreased insulin sensitivity and responsiveness (26). The strong correlation observed in this study between the fasting insulin levels and TNF- $\alpha$ expression in fat tissue may also suggest that TNF- $\alpha$ expression is closely associated with peripheral insulin resistance since there is no fasting hyperglycemia in the subjects studied. Taken together, these results indicate that the mechanistic bases of peripheral and hepatic insulin resistance may not be identical in obesity and the role of TNF$\alpha$ in obesity-linked insulin resistance may be restricted to extrahepatic insulin resistance primarily by influencing the steps distal to insulin receptor binding. Further studies will be necessary to address these possibilities.

Finally, several indirect lines of evidence besides the data presented here suggest that TNF- $\alpha$ may play a potentially important pathophysiological role in human obesity and NIDDM. First, recent genetic studies using sibling pair analysis have shown linkage between a polymorphism in the TNF- $\alpha$ locus and body fat content and BMI in Pima indians (27). Second, during the use of pentoxifylline for the treatment of vascular complications in NIDDM patients, an increase has been observed in insulin sensitivity (28). It is now known that pentoxyfylline is an inhibitor of TNF- $\alpha$ production although not a very potent one (29). These studies however, are preliminary and must await further confirmation in different groups of obese humans.

In summary, the observations presented here, taken together with earlier studies showing a functional role for TNF- $\alpha$ in animal models of obesity-linked insulin resistance, suggest that aberrant expression of TNF- $\alpha$ in adipose tissue may also be a component of the insulin resistance in obese humans. Since recent studies indicate that agents which improve insulin sensitivity may be of great value in the treatment of NIDDM (30) it is of interest to test whether insulin resistance and its clinical correlates can be reversed by therapies aimed at the neutralization of TNF- $\alpha$. Clinical trials to definitively address this possibility are clearly needed.

\section{Acknowledgments}

We would like to thank David L. Murray for technical help.

This work was supported by Swedish Medical Research Council, Swedish Diabetes Association, and Novo-Nordick Insulin Foundation (P. Arner), National Institutes of Health, (DK 42539 [B. M. Spiegelman], and DK 45592 [J. F. Caro]) and American Diabetes Association (G. S. Hotamisligil).

\section{References}

1. Bennet, P. H. 1990. Epidemiology of diabetes mellitus. In Diabetes Mellitus. H. Rifkin, and J. D. Porte, editors. Elsevier Science Publishing Co., Inc., New York. 357-377.

2. Moller, D. E., and J. S. Flier. 1992. Insulin resistance: mechanisms, syndromes, and implications. N. Engl. J. Med. 325:938-948.

3. Olefsky, J. M., and J. M. Molina. 1990. Insulin resistance in man. In Diabetes Mellitus. H. Rifkin and J. D. Porte, editors. Elsevier Science Publishing Co., Inc., New York. 121-153.

4. Himmsworth, H. P. 1939. The mechanisms of diabetes mellitus. IV. Human diabetes mellitus. Lancet. ii:171-176.

5. Old, L. J. 1985. Tumor necrosis factor (TNF). Science (Wash. DC). 230:630-633.

6. Pennica, D., G. E. Nedwin, J. S. Hayflick, P. H. Seeburg, R. Derynck, M. A. Palladino, W. J. Kohr, B. B. Aggarwal, and D. V. Goeddel. 1984. Human tumor necrosis factor: precursor structure, expression and homology to lymphotoxin. Nature (Lond.). 312:724-727.

7. Beutler, B., and A. Cerami. 1989. The biology of cachectin/TNF- $\alpha$ primary mediator of the host response. Annu. Rev. Immunol. 7:625-655.

8. Grunfeld, C., and K. R. Feingold. 1991. The metabolic effects of tumor necrosis factor and other cytokines. Biotherapy. 3:143-158.

9. Hotamisligil, G. S., N. S. Shargill, and B. M. Spiegelman. 1993. Adipose expression of tumor necrosis factor-alpha: direct role in obesity-linked insulin resistance. Science (Wash. DC). 259:87-91.

10. Hotamisligil, G. S., and B. M. Spiegelman. 1994. TNF- $\alpha$ : a key component of obesity-diabetes link. Diabetes. 43:1271-1278.

11. Hofmann, C., K. Lorenz, S. S. Braithwaite, B. J. Palazuk, G. S. Hotamisligil, and B. M. Spiegelman. 1994. Altered gene expression for tumor necrosis factor- $\alpha$ and its receptors during drug and dietary modulation of insulin resistance. Endocrinology. 134:264-270.

12. Folli, F., M. J. Saad, J. M. Backer, and C. R. Kahn. 1992. Insulin stimulation of phosphatidylinositol 3-kinase activity and association with insulin receptor substrate 1 in liver and muscle of the intact rat. J. Biol. Chem. 267:22171-22177.

13. Heydrick, S. J., D. Jullien, N. Gautier, J.-F. Tanti, S. Giorgetti, E. van Obberghen, and Y. Le Marchand-Brustel. 1993. Defect in skeletal muscle phosphatidylinositol-3'-kinase in obese insulin-resistant mice. J. Clin. Invest. 91:1358-1366.

14. Saad, M. J. A., E. Araki, M. Miralpeix, P. L. Rothenberg, M. F. White, and C. R. Kahn. 1992. Regulation of insulin receptor substrate-1 in liver and muscle of animal models of insulin resistance. J. Clin. Invest. 90:1839-1849.

15. Thies, R. S., J. M. Molina, T. P. Ciaraldi, G. R. Freidenberg, and J. M. Olefsky. 1990. Insulin-receptor autophosphorylation and endogenous substrate phosphorylation in human adipocytes from control, obese, and NIDDM subjects. Diabetes. 39:250-259.

16. Friedenberg, G. R., R. R. Henry, H. H. Klein, D. R. Reichart, and J. M. Olefsky. 1987. Decreased kinase activity of insulin receptors from adipocytes of non-insulin-dependent diabetic subjects. J. Clin. Invest. 79:240-250.

17. Feinstein, R., H. Kanety, M. Z. Papa, B. Lunenfeld, and A. Karasik. 1993. Tumor necrosis factor- $\alpha$ suppresses insulin-induced tyrosine phosphorylation of insulin receptor and its substrates. J. Biol. Chem. 268:26055-26058.

18. Hotamisligil, G. S., D. L. Murray, L. N. Choy, and B. M. Spiegelman. 
1994. TNF- $\alpha$ inhibits signaling from insulin receptor. Proc. Natl. Acad. Sci. USA. 91:4854-4858.

19. Hotamisligil, G. S., A. Budavari, D. L. Murray, and B. M. Spiegelman. 1994. Reduced tyrosine kinase activity of the insulin receptor in obesity-diabetes: central role of tumor necrosis factor- $\alpha$. J. Clin. Invest. 94:1543-1549.

20. Chirgwin, J. M., A. E. Przybyla, R. J. MacDonald, and W. J. Rutter. 1979. Isolation of biologically active ribonucleic acid from sources enriched in ribonuclease. Biochemistry. 18:5294-5299.

21. Spiegelman, B. M., M. Frank, and H. Green. 1983. Molecular cloning of mRNA from 3T3 adipocytes. Regulation of mRNA content for glycerolphosphate dehydrogenase and other differentiation-dependent proteins during adipocyte development. J. Biol. Chem. 258:10083-10089.

22. Gray, P. W., B. B. Aggarwal, C. V. Benton, T. S. Bringman, W. J. Henzel, J. A. Jarret, D. W. Leung, B. Moffat, P. Ng, L. P. Svedersky, et al. 1984. Cloning and expression of cDNA for human lymphotoxin, a lymphokine with tumor necrosis activity. Nature (Lond.). 312:721-724.

23. Moses, A. C., and M. J. Abrahamson. 1993. Therapeutic approaches to insulin resistance. In Insulin Resistance. D. E. Moller, editor. John Wiley \& Sons Ltd., Chicester, United Kingdom. 385-410.

24. Bjorntorp, P. 1992. Regional Obesity. In Obesity. P. Bjorntorp and B. D. Brodoff, editors. J. B. Lippincott. Philadelphia. 579-586.
25. Boeck, M. A., C. Chen, and S. Cunningham-Rundles. 1993. Altered immune function in a morbidly obese pediatric population. Ann. NY Acad. Sci. 699:252-256.

26. Prager, R., P. Wallace, and J. M. Olefsky. 1986. In vivo kinetics of insulin action on peripheral glucose disposal and hepatic glucose output in normal and obese subjects. J. Clin. Invest. 78:472-481.

27. Norman, R. A., C. Bogardus, and E. Ravussin. 1994. Linkage of obesity with a DNA marker near the tumor necrosis factor- $\alpha$ locus. Int. J. Obes. 18(Suppl. 2):11.

28. Raptis, S., A. Mitrakou, D. Hadjidakis, E. Diamantopoulos, C. Anastasiou, A. Fountas, and R. Muller. 1987. 24-h blood glucose pattern in type I and type II diabetics after oral treatment with pentoxifylline as assessed by artificial endocrine pancreas. Acta Diabetol. Lat. 24:181-192.

29. Strieter, R. M., D. G. Remick, P. A. Ward, R. N. Spengler, J. P. Lynch III, J. Larrick, and S. L. Kunkel. 1988. Cellular and molecular regulation of tumor necrosis factor-alpha production by pentoxifylline. Biochem. Biophys. Res. Commun. 155:1230-1236.

30. Nolan, J. J., B. Ludvik, P. Beerdsen, M. Joyce, and J. M. Olefsky. 1994. Improvement in glucose tolerance and insulin resistance in obese subjects treated with troglitazone. $N$. Engl. J. Med. 331:1188-1193. 